\title{
Past, Present and Future
}

\section{Peter Corr} MBChB, FFRad(D)SA, FRCR, M Med(UCT)

Head: Department of Radiology, University of Natal
W elcome to the "New SAJR". The society has decided to continue with the journal after a break of 12 months. There are many reasons why South African radiology needs a journal. Perhaps the most important is to advertise to our colleagues the important role radiologists play in modern medical practice. I never cease to be amazed by how ignorant many of our colleagues are about what we do. This poor local perception is in contradistinction to the prestigious image radiology has in Europe and North America. We have only ourselves to blame.

I have taken the opportunity to invite a number of colleagues to write about the past, the present and more importantly the future of radiology both in a local South African and an international context. I hope you enjoy this millennial edition and that it stimulates you to write to us with your comments and suggestions?

\section{Peter Corr}

Editor 